\title{
Investigating the Effect of Gasoline Prices on Transit Ridership and Unobserved Heterogeneity
}

\author{
Hojin Jung, Gun Jea Yu, and Kyoung-Min Kwon \\ Hongik University
}

\begin{abstract}
Based on a unique scanner panel data set on debit and credit card transactions, we examined the effect of gasoline prices on individual choices between private vehicle use and public transit ridership. The unique feature of our data allowed us to address possible heterogeneity in the effect of gasoline prices and to explicitly incorporate the link between private vehicle use and public transit ridership. A series of empirical analyses reveal that there is significant heterogeneity in the effect of gasoline prices on fuel consumption and that financial constraints and commitment to vehicle use determine individual sensitivities to the price of gasoline. The substantive empirical knowledge provided about individual decisions concerning transit modes contributes meaningful implications and effective guidance for practitioners and policymakers.
\end{abstract}

Key words: Public transit ridership, private vehicle use, gasoline prices, heterogeneity

\section{Introduction}

In accordance with growing concerns about increasing levels of carbon and energy security, many industrialized nations and organizations have begun to advocate for transformation of the energy market, and firms have begun to make extensive investments in sustainable energy products and services. However, many parts of the globe still heavily rely on oil, coal, and natural gas, and such fossil fuels are the primary resources used to heat homes, run vehicles, and power industry. In particular, fossil fuels meet $85 \%$ of the total energy requirement and $95 \%$ of transportation-sector consumption in the US (Economy Watch 2010). Similar patterns also are witnessed in other industrialized countries-for instance, in $2014,66 \%$ of the total electricity generated in Korea, which was investigated in this paper, was accounted for by fossil fuels (U.S. Energy Information Administration 2015). 
Under such circumstances, recent fluctuations in gasoline prices reignited interests in understanding gasoline demand, and numerous studies in different fields have been compiled to predict the impact of policy interventions on gasoline consumption (e.g., Dahl 1996; Dahl and Sterner 1991; Drollas 1984; Espey 1997; Sterner 1990). One particular object of these studies has been to understand how the price of gasoline influences ridership on public transportation, focusing on shorter time horizons in which it is not feasible for people to alter their commitment to fuel consumption or to buy more fuel-efficient cars (Golub 2010; Mattson 2008). Such a discussion is important because the use of fossil fuels by private and public transportation systems has been increasing significantly over the years, and fossil fuels currently account for $44.9 \%$ of the total refined products derived from crude oil. Furthermore, those affected by the resultant costs of private vehicle use, such as noise emission and increased levels of pollution, are not limited to motorists (Economy Watch 2010; Institute for Energy Research 2015).

However, studies in this stream typically are conducted at an aggregate level, and the link between private vehicle use and public transit ridership has hardly been addressed explicitly. As a result, little is known about how individuals react to gasoline prices or to policy interventions or about how the individual mode choices are made. Yet the literature shows that there is significant heterogeneity in individual responses to fluctuations in prices (e.g., Kim and Rossi 1994; Wakefield and Inman 2003) and that the purchase decision of a product is directly related to that of its substitutes in many other contexts (Allenby et al. 2004; Anderson and Simester 1998; Dube and Gupta 2008). Thus, the common restriction imposed in these studies allows only limited implications about the demand for gasoline and ridership on public transit to be extrapolated.

Such an absence is surprising, considering that the environmental problems resulting from fossil fuel use and related industries are of extreme importance to the economy. A key contributing reason for the limited work exploring individual responses to fluctuations in gasoline prices is the lack of microdata on individual decisions in the two categories. Unlike in many other retail industries for which scanner panel data have been used extensively in research on differences in individual behaviors, panel data on purchases of or expenditures on fuel and transit ridership have not been widely accessible to academics.

In this study, we examined the effect of gasoline prices on individual choices between private vehicle use and public transit ridership based on a unique scanner panel data set on debit and credit card transactions. Through a series of empirical analyses, we explicitly addressed possible heterogeneity in the effect across individuals and present robust evidence that, with significant heterogeneity across individuals, gasoline prices have a statistically and economically significant effect on fuel consumption and public transit ridership. The substantive empirical knowledge provided herein about individual decisions concerning transit modes contributes meaningful implications and effective guidance for practitioners and policymakers.

The paper proceeds as follows. Section 2 discusses the relevant literature, and Section 3 explains the data. Section 4 presents the empirical models and their results. Section 5 
describes robustness checks of our findings, Section 6 addresses the implications of our findings, and Section 7 concludes.

\section{Related Literature}

Extensive studies have been conducted to explore how the demand for gasoline changes in response to fluctuating or rising gasoline prices. A wide range of assumptions and model specifications has been employed to investigate data across different time periods and regions, yielding predictions about the impact of policy interventions and explanations about differences in gasoline consumption (Dahl 1986; Dahl and Sterner 1991; Drollas 1984; Schipper et al. 1993; Sterner 1990). Several meta-analyses have summarized the estimates of price or income elasticities in past research and explained the variations in the results across studies (Assmus 1984; Espey 1997; Espey 1998; Tellis 1988).

An interesting feature of such efforts is that researchers tend to pay particular attention to different margins over which different market players make adjustments. For example, Donna (2010), Wang and Chen (2014), and Goldberg (1998) investigated how, in the short run, drivers alter how much they drive when gasoline prices change; Busse et al. (2012) examined whether car buyers buy more fuel-efficient cars in response to increasing gasoline prices in the medium run; and Gramlich (2009) explored whether gasoline prices impact decisions of automobile manufacturers concerning the fuel economy of vehicles they produce in the long run. Because the adjustments that can be made over different time horizons can differ considerably, no simple answers can describe how gasoline prices affect gasoline usage completely. Nonetheless, conventional wisdom is that the demand for gasoline is fairly inelastic over short time horizons, on which we focus in this paper.

Beyond the demand for gasoline, ridership on public transit also has been examined in systematic research investigating the impact of gasoline prices. A noteworthy finding presented in many of these studies is that an increase in gasoline prices has a statistically-significant but economically-marginal effect on transit ridership in the short run (e.g., Agathe and Billings 1978; Masayuki and Allen 1986; Navin 1974; Nizlek and Duckstein 1974; Rose 1986; Wang and Skinner 1984; Wolff and Clark 1982). For example, cross-elasticity estimates for transit ridership due to gasoline prices typically fall below 0.15 in the short run, whereas longer-run estimates range from 0.12 to 0.40 (Mattson 2008).

However, there are mixed empirical findings about how the short-run impact of gasoline varies across the population. For example, McLeod et al. (1991) modeled gasoline price as an important determinant of transit ridership but found no evidence that it is a significant factor. Kitamura (1989) raised the issue of interrelationship between car use and transit ridership and found that a change in car use influences transit use.

To explain such mixed empirical results, researchers consider that various factors such as parking, fuel, transit quality, and transit fare prices have some interaction with ridership on public transit under conditions of changing gasoline prices. For example, 
the low-income population suffers more from rising gasoline prices as a result of limited transit options; substantial transit systems enable a realistic alternative for large segments of the population, resulting in a larger mode-choice response to gasoline price changes; and the modal shift to public transit first occurs among travelers making the most expensive automobile trips (Currie and Phung 2007; Haire and Machemehl 2007; Litman 2004; Mattson 2008; McFadden and Talvitie 1977; Sanchez 1999; Sanchez and Peng 2004; Wang and Skinner 1984).

We contribute to these lines of research, in that our analyses allow for a comprehensive understanding of the individual decisions between the use of one's private vehicle and ridership on public transit during periods of fluctuating gasoline prices. Given the significant role of transportation agencies in the transit ridership (Agathe and Billings 1978; Horowitz 1982; Navin 1974; Sagner 1974), the considerable advantage of our data provides important implications about how policy changes would influence members of the population with different characteristics.

\section{Data}

Our data came from a company that developed a household account-book application. The application automatically records credit and debit card transactions based on text messages its users receive on their cell phones. The information collected from the text message includes for each transaction the customer's individual identifier, date and time, amount paid, name of the retail store, and retailer type (identified based on its name). The application exclusively serves Koreans, and, thus, our data were limited to transactions of Korean customers. Yet, given the construct of the data collection process, transaction information included in the data is not limited to particular categories, and the application records data for an extensive range of expenses.

Our data set included the records of retail transactions of 12,000 individuals in 2014. The sample was randomly drawn by the company from its entire customer pool. Examining transaction information for these 12,000 individuals, however, we identified that only 1,521 individuals had made at least one purchase of a transit card or an individual trip by public transit (bus or rail). Because our study aimed to investigate the impact of gasoline prices with a particular focus on public transit ridership as well as on the demand for gasoline, we restricted our attention to these 1,521 individuals for further empirical analyses.

Table 1 describes the transaction information of 12,000 (full sample) and 1,521 (estimation sample) individuals. Of a total monthly expenditure of 832,538 won, an average individual in the estimation sample spent 74,284 won on gasoline and 43,513 won on public transit. Similarly, an average individual in the full sample spent 73,874 won on gasoline out of total monthly expenditures of 824,283 won, although the expenditures on public transit in this group were much smaller than those of the estimation sample. Given the construction of the estimation sample, the considerable differences in expenditures on public transit are intuitive. 
TABLE 1.

Descriptive Statistics for Monthly Expenditures

\begin{tabular}{|l|c|c|}
\hline \multicolumn{1}{|c|}{ Average Weekly Expenditures } & Estimation Sample (won) & Full Sample (won) \\
\hline Total expenditures & 832,538 & 824,283 \\
\hline Gasoline & 74,284 & 73,874 \\
\hline Public transportation (bus, subway, or train) & 43,513 & 5,515 \\
\hline
\end{tabular}

\section{Descriptive Analysis}

In 2014, oil prices dropped dramatically. Beginning at $\$ 107.33$ on January 2, benchmark crude fell below $\$ 100$ in March and, in July, reached \$66.90, its lowest value since 2008. By December, the price of benchmark crude oil dropped to $\$ 62.75$, representing a $40 \%$ decrease for the year. As a net importer of crude oil, Korea exhibited similar patterns in the price of gasoline, and retail prices in Korea consistently fell throughout 2014, as described in Figure 1. Although Figure 1 suggests, compared to the drop in oil prices, a relatively small decrease in the retail price of gasoline in 2014, note that gasoline prices retreat slowly when oil prices fall.

FIGURE 1. Median gasoline prices, 2014 (won per liter)

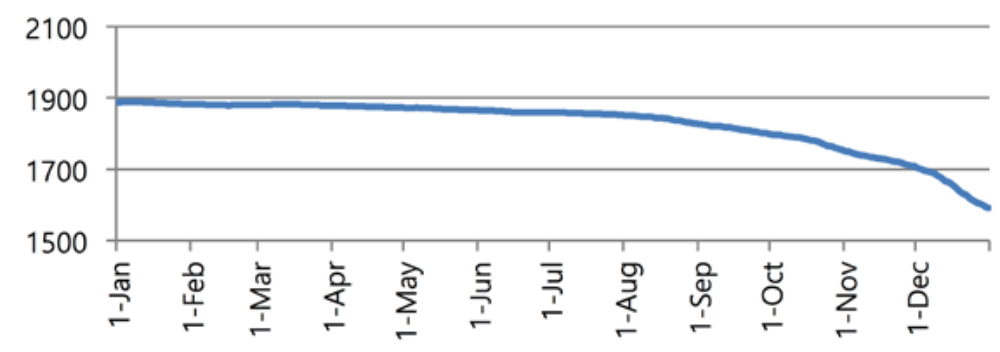

Upon finding the considerable and consistent drop in gasoline prices throughout 2014, we focused on the effect of gasoline prices on fuel consumption and transit ridership. In particular, we first calculated individual monthly expenditures on gasoline and transit ridership and examined whether any particular patterns were to be found in relation to the persistent decrease in gasoline prices. According to the extant literature on the effect of gasoline prices, the population should switch to private vehicles from public transit, although not to a dramatic extent, and transit expenditures, therefore, were expected to decrease during the sample period.

Figure 2 shows graphs of the two types of expenditures. The first interesting feature to be noted in Figure 2 is that the average monthly expenditures on public transit gradually decreased throughout 2014, as predicted based on the decrease in gasoline prices. Considering that fares for public transportation remained stable during the sample period, the gradual but steady decrease in expenditures on public transit empirically support the argument that the demand for public transport decreased during the period with falling gasoline prices. 
FIGURE 2.

Average monthly expenditures, 2014 (won)

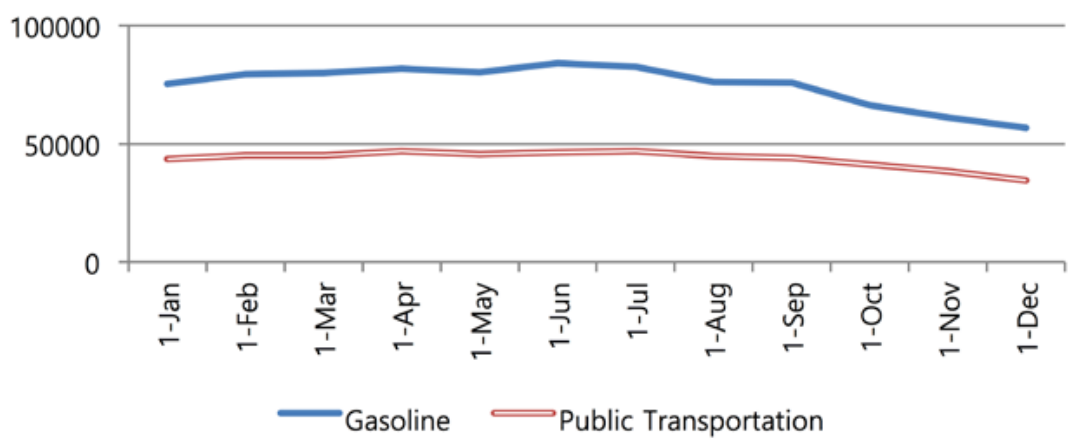

Turning to the average monthly expenditures on gasoline, Figure 2 implies that the population generally reduced their gasoline expenditures during 2014. Such a decrease in gasoline expenditures may seem to imply a decrease in fuel usage at first glance. However, note that the decrease in gasoline expenditures was modest relative to the dramatic decrease in retail gasoline prices in 2014. Together with the decrease in expenditures on public transit, this suggests that the population increased their gasoline consumption as retail gasoline prices decreased by switching to private vehicle use from transit ridership. However, we caution that the approach we adopted in this subsection is more descriptive and may not be well suited to conclusively validate this conclusion.

Given the descriptive evidence about the impact of gasoline prices on transit mode choice, we noted that transit commuters often use transportation cards to avoid the hassle of purchasing single-journey tickets. Although many credit and debit cards provide transit card services, the absence of a concrete link between the expenditure and transit ridership could introduce a bias into our result. Thus, we calculated summary statistics for transactions made for public transportation and compared them with the public transportation fares. Table 2 shows that the three quartiles of these transactions were fairly similar to minimum transit fares, whereas the average was approximately three times the minimum bus fare. We, therefore, considered the that summary statistics reported in Table 2 provide empirical evidence that transit riders used their debit and/or credit cards as transit cards and ensured that the expenditures on public transit could serve a proxy for transit ridership.

TABLE 2.

Descriptive Statistics for Public Transit Transactions

\begin{tabular}{|l|c|c|c|}
\hline \multicolumn{2}{|c|}{$\begin{array}{c}\text { Public Transit Fares } \\
\text { (Minimum) }\end{array}$} & \multicolumn{2}{c|}{$\begin{array}{c}\text { Transaction for } \\
\text { Public Transportation }\end{array}$} \\
\hline Bus & 1,200 won & $1^{\text {st }}$ Quartile & 1,550 won \\
\hline Subway & 1,250 won & Median & 1,200 won \\
\hline & & $3^{\text {rd }}$ Quartile & 1,200 won \\
\hline & & Average & 3,786 won \\
\hline
\end{tabular}

\section{Gasoline Prices and Individual Decisions of Transit Modes}

Based on the descriptive evidence for the effect of gasoline prices, we developed models of weekly expenditures on gasoline and public transit as a function of gasoline prices. The models examine how the changes in gasoline prices influenced weekly 
expenditures on gasoline and public transit, respectively, after explicit controlling for other explanatory variables. Beyond the price of gasoline, the models include two groups of explanatory variables. The first group controls for the effect of heterogeneity in preferences across individuals, using demographic information and individuals' value of the dependent variable during an initialization period (Briesch et al. 2009; Bucklin et al. 1995; Ma et al. 2011). More specifically, data during the first four weeks of our sample period were employed to construct the initialization period dependent value and then excluded in the further analyses to avoid a possible endogeneity. Finally, the second group accounts for time trends and general economic conditions.

Turning to the effect of gasoline prices, we noted that it may have taken more than a week for people to react to the changes in gasoline prices and that gasoline prices may have influenced individual transit mode-choices with a time lag. Although we considered that the advanced public transit system enabled a realistic alternative in the very short run, we, thus, included the lagged gasoline prices and tested the effect of lagged gasoline prices on their gasoline consumption and transit ridership.

The model of gasoline expenditures employs log-log form, and the estimation results provide coefficients in percentages instead of absolute terms. This is because considerable variations are present in the magnitude of the expenditures on gasoline and public transit across individuals. Log-log linear specification is widely employed by studies exploring the effect of gasoline prices on consumer expenditures in different categories (Gicheva et al. 2010; Ma et al., 2012). The model is in the following form:

$\log$ GasExp $_{i t}=\alpha_{1}^{1}+\beta_{1}^{1} \log$ GasExp $_{0 i}+\beta_{1}^{2}$ Demog $_{i}+\gamma_{1}^{1} \log$ Price $_{t}+\gamma_{1}^{2} \log$ Price $_{t-1}+\delta_{1}^{1} X_{t}+\varepsilon_{1 i t}^{1}$

The dependent variable, GasExp ${ }_{i t}$, is individual $i$ 's expenditures on gasoline for week

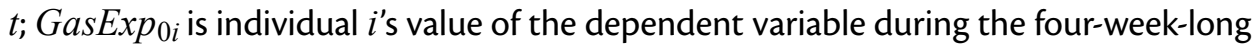
initialization period; $\operatorname{Demog}_{i}$ is a group of demographic variables, including dummies indicating gender and age; Price $_{t}$ and Price $_{t-1}$, the variables of primary interest, are the average retail price of gasoline at week $t$ and $t-1$; and $X_{t}$ is a set of controls, including dummies for time trends and age groups.

Similarly, the model of expenditures on public transit is specified as a function of the same explanatory groups, with individual $i$ 's expenditures on public transit for week $t$, PubExp ${ }_{i t}$, as the dependent variable. This model is also specified in log-log form:

$\log$ PubExp $p_{i t}=\alpha_{2}^{1}+\beta_{2}^{1} \log$ GasExp $_{0 i}+\beta_{2}^{2}$ Demog $_{i}+\gamma_{2}^{1} \log$ Price $_{t}+\gamma_{2}^{2} \log$ Price $_{t-1}+\delta_{2}^{1} X_{t}+\varepsilon_{2 i t}^{1}$

Table 3 summarizes the estimation results based on 1,521 individuals who had made at least one purchase of a transit card or an individual trip by public transit. First focusing on the impact of gasoline prices on gasoline consumption, a decrease in gasoline prices was associated with a statistically-significant decrease in gasoline expenditures. In particular, weekly gasoline expenditures decreased by $0.65 \%$ for a $1 \%$ decrease in the retail price of gasoline, implying that the elasticity of demand for gasoline is -0.35 $\left(\frac{1-\frac{1-0.0065}{1-0.01}}{1-0.99}=\frac{-0.0035}{0.01}\right)$. This is consistent with the extensive literature on gasoline demand, 
in which the elasticity of gasoline demand turns out to be between 0 and -1.36 (Espey 1998). Turning to the effect of lagged gasoline prices, $\gamma_{2}^{2}$ also turned out statisticallysignificant, showing that a $1 \%$ decrease in the retail gasoline prices would result in a $0.10 \%$ decrease in the gasoline expenditures for the following week.

TABLE 3.

Estimation Results for Log Expenditures Models

\begin{tabular}{|c|c|c|}
\hline & Gasoline & Public Transportation \\
\hline Expenditures during initialization period & $\begin{array}{l}0.4982^{* *} \\
(0.0065)\end{array}$ & $\begin{array}{l}0.1865^{* *} \\
(0.0248)\end{array}$ \\
\hline Gasoline prices & $\begin{array}{c}0.6257^{* *} \\
(0.1854)\end{array}$ & $\begin{array}{l}0.1714^{* *} \\
(0.2014)\end{array}$ \\
\hline Lagged gasoline prices & $\begin{array}{l}0.1054^{* *} \\
(0.0425)\end{array}$ & $\begin{array}{c}0.0854^{* *} \\
(0.0352)\end{array}$ \\
\hline Gender dummy & $\begin{array}{c}0.0015 \\
(0.0385)\end{array}$ & $\begin{array}{c}0.0063 \\
(0.0284)\end{array}$ \\
\hline 2nd quarter & $\begin{array}{c}0.1247^{*} \\
(0.0524)\end{array}$ & $\begin{array}{c}0.0021 \\
(0.0725)\end{array}$ \\
\hline 3rd quarter & $\begin{array}{c}0.0854 \\
(0.0695)\end{array}$ & $\begin{array}{c}0.0254 \\
(0.0621)\end{array}$ \\
\hline 4th quarter & $\begin{array}{c}0.2148^{*} \\
(0.0895)\end{array}$ & $\begin{array}{c}0.0084 \\
(0.0685) \\
\end{array}$ \\
\hline $30 \mathrm{~s}$ & $\begin{array}{l}0.6257^{* *} \\
(0.0485)\end{array}$ & $\begin{array}{c}-0.2857^{* *} \\
(0.0254)\end{array}$ \\
\hline $40 \mathrm{~s}$ & $\begin{array}{l}0.8571^{* *} \\
(0.0621)\end{array}$ & $\begin{array}{c}-0.4965^{* *} \\
(0.0758)\end{array}$ \\
\hline $50 \mathrm{~s}$ & $\begin{array}{l}0.7848^{* *} \\
(0.0895)\end{array}$ & $\begin{array}{c}-0.4896^{* *} \\
(0.1054)\end{array}$ \\
\hline $60 \mathrm{~s}$ & $\begin{array}{l}1.2147^{* *} \\
(0.4254)\end{array}$ & $\begin{array}{c}-0.8745^{* *} \\
(0.0895)\end{array}$ \\
\hline Intercept & $\begin{array}{c}-1.2547^{*} \\
(0.4785)\end{array}$ & $\begin{array}{l}0.4258^{* *} \\
(0.0895)\end{array}$ \\
\hline $\mathrm{N}$ & 72,479 & 72,954 \\
\hline Adjusted R-squared & 0.108 & 0.076 \\
\hline
\end{tabular}

${ }^{*} p<0.05 ;{ }^{* *} p<0.01$

Note: Standard errors are shown in parentheses.

In the model of expenditures on public transit, the coefficient of gasoline prices also turned out to be statistically-significant and positive. The results suggest that weekly expenditures on public transit decrease by $0.17 \%$ for a $1 \%$ decrease in the retail price of gasoline for an average individual, implying that cross-elasticities for transit ridership are 0.17 . Finally, similar to the model of gasoline expenditures, the effect of lagged gasoline prices also was statistically significant but smaller than the effect of gasoline prices.

The cross-elasticities for transit ridership were somewhat higher than those reported in the extant studies (Mattson 2008). Remember that Korea has one of the world's most advanced public-transportation infrastructures, and local urban taxis, buses, and subways provide exceptionally good and punctual service at fairly low fares. Thus, we considered our estimation results to be in line with our prediction. To summarize, our 
interpretation of the statistically-significant effects of gasoline prices in the two models is that the population switches to private vehicle use from ridership on public transit when gasoline prices increase.

In addressing the effect of gasoline prices on gasoline consumption and transit ridership, we understand that different factors such as the availability of parking, gasoline prices, transit quality, and transit fares have considerable impact on mode choices (Bhat et al. 2009; Litman 2004; Taylor and Fink 2003; Wang and Skinner 1984). Although, among these factors, only the effect of gasoline prices is incorporated in our empirical analyses, our analyses focused on a short time horizon over which no particular systematic changes in the availability of parking, transit quality, or transit fares were likely to occur. Thus, we concluded that although our empirical analyses could not account for the effects of other factors, concerns about the omitted variable bias are not valid, despite that the findings cannot provide implications about the effects of other factors.

Finally, upon finding the intuitive results, we evaluated the robustness of our findings. We noted that there were different lengths of initialization periods or other model specifications that we could consider. Thus, we replicated the analyses by varying the length of the initialization period and using alternative model specifications. In particular, we used a six-week-long initialization period (Model 3) and a fixed-effects estimation to control for heterogeneity in preferences across individuals (Model 4).

Tables 4 and 5 report the findings for all of the replications. To summarize, the effects of gasoline prices are all statistically significant and positive despite the loss in the model fit in terms of $R$-squared, showing that the results after these adjustments were qualitatively unchanged. Our findings survived all the above robustness checks and provide strong empirical evidence that gasoline prices have statistically significant effects on gasoline expenditures and ridership on public transit.

TABLE 4.

Estimation Results for Competing Models (Fixed Effect)

\begin{tabular}{|l|c|c|}
\hline & Gasoline & Public Transportation \\
\hline Gasoline prices & $\begin{array}{c}0.5214^{* *} \\
(0.2014)\end{array}$ & $\begin{array}{c}0.1685^{* *} \\
(0.0621)\end{array}$ \\
\hline Lagged gasoline prices & $\begin{array}{c}0.1102^{* *} \\
(0.0036)\end{array}$ & $\begin{array}{c}0.0632^{* *} \\
(0.0221)\end{array}$ \\
\hline \multirow{2}{*}{ 2nd quarter } & $\begin{array}{c}0.1247^{* *} \\
(0.0501)\end{array}$ & $\begin{array}{c}0.0042 \\
(0.0510)\end{array}$ \\
\hline 3rd quarter & $\begin{array}{c}0.1301 \\
(0.0701)\end{array}$ & $\begin{array}{c}0.0421 \\
(0.0681)\end{array}$ \\
\hline \multirow{2}{*}{ 4th quarter } & $\begin{array}{l}0.2014^{*} \\
(0.1109\end{array}$ & $\begin{array}{c}0.0041 \\
(0.0874)\end{array}$ \\
\hline Intercept & $2.8921^{* *}$ & $5.8654^{* *}$ \\
$(1.0852)$ & $(1.2014)$ \\
\hline N & 72,479 & 72,954 \\
\hline Adjusted R-squared & 0.0009 & 0.0008 \\
\hline F & 8.65 & 4.87 \\
\hline
\end{tabular}

${ }^{*} p<0.05 ;{ }^{* *} p<0.01$

Note: Standard errors are shown in parentheses. 
TABLE 5.

Estimation Results for Competing Models (6-week initialization period)

\begin{tabular}{|c|c|c|}
\hline & Gasoline & Public Transportation \\
\hline Expenditures during initialization period & $\begin{array}{l}0.4847^{* *} \\
(0.0084)\end{array}$ & $\begin{array}{l}0.1758^{* *} \\
(0.0249)\end{array}$ \\
\hline Gasoline prices & $\begin{array}{l}0.6244^{* *} \\
(0.2044)\end{array}$ & $\begin{array}{l}0.1687^{* *} \\
(0.1994)\end{array}$ \\
\hline Lagged gasoline prices & $\begin{array}{l}0.1001^{* *} \\
(0.0357)\end{array}$ & $\begin{array}{l}0.0862^{* *} \\
(0.0301)\end{array}$ \\
\hline Gender dummy & $\begin{array}{c}0.0018 \\
(0.0412)\end{array}$ & $\begin{array}{l}-0.0052 \\
(0.0251)\end{array}$ \\
\hline 2nd quarter & $\begin{array}{c}0.0987 \\
(0.0702)\end{array}$ & $\begin{array}{c}0.0047 \\
(0.0621)\end{array}$ \\
\hline 3rd quarter & $\begin{array}{c}0.0725 \\
(0.0709)\end{array}$ & $\begin{array}{c}0.0321 \\
(0.0471)\end{array}$ \\
\hline 4th quarter & $\begin{array}{l}0.2111^{* *} \\
(0.0987)\end{array}$ & $\begin{array}{c}0.0074 \\
(0.0687)\end{array}$ \\
\hline $30 \mathrm{~s}$ & $\begin{array}{l}0.4214^{* *} \\
(0.0387) \\
\end{array}$ & $\begin{array}{c}-0.4461^{* *} \\
(0.0451)\end{array}$ \\
\hline $40 \mathrm{~s}$ & $\begin{array}{l}0.8541^{* *} \\
(0.0701)\end{array}$ & $\begin{array}{c}-0.6582^{* *} \\
(0.0541)\end{array}$ \\
\hline $50 \mathrm{~s}$ & $\begin{array}{c}0.7214^{* *} \\
(0.1541)\end{array}$ & $\begin{array}{c}-0.5650^{* *} \\
(0.0922)\end{array}$ \\
\hline $60 \mathrm{~s}$ & $\begin{array}{l}1.0974^{* *} \\
(0.2417) \\
\end{array}$ & $\begin{array}{c}-0.6939^{* *} \\
(0.1759) \\
\end{array}$ \\
\hline Intercept & $\begin{array}{c}-1.8741^{* *} \\
(0.1587) \\
\end{array}$ & $\begin{array}{c}0.6820^{* *} \\
(0.2126) \\
\end{array}$ \\
\hline $\mathrm{N}$ & 69,492 & 69,914 \\
\hline Adjusted R-squared & 0.101 & 0.052 \\
\hline
\end{tabular}

${ }^{*} p<0.05 ;{ }^{* *} p<0.01$

Note: Standard errors are shown in parentheses.

\section{Heterogeneity in Consumer Responses to Changes in Gasoline Prices}

There is ample evidence that individual characteristics have a significant effect on price sensitivities in many purchase contexts (e.g., Hoch et al. 1995). Studies on gasoline demand and public transit ridership also have addressed different individual characteristics and have particularly focused on the role of income. For example, Golub (2010) noted that, in addition to ownership costs, marginal costs during periods of rising gasoline prices become particularly significant for low-income households and affect their ability to use vehicles for commuting to a considerable extent. Thus, we incorporated the effect of financial constraints into our consideration and explored the interactions between income and gasoline prices. Without a direct measure of income in the data, we found a variable that could approximate the financial constraints with which individuals are faced. More specifically, based on the recognition that consumption expenditures are closely related to financial constraints (Cutler and Katz 1991; Johnson and Smeeding 1998), using the total amount of expenditures for a 
four-week-long initialization period, we constructed a measure of individual financial constraints.

We also note that, apart from the effect of income, substantial variations are present in individual gasoline expenditures, as described in Table 6. More specifically, the top $25 \%$ of the sample in terms of gasoline consumption spent more than 12 times as much on gasoline as the bottom $25 \%$ of the sample. We posited that an increase or decrease in gasoline prices, therefore, likely would not influence the population equally, as large variations in gasoline expenditures should lead to considerable heterogeneity in individuals' incentives to adjust their fuel use. For example, the population exhibiting greater gasoline consumption would be faced with a larger increase in gasoline expenditures for a won increase in gasoline prices and would therefore have larger incentives to adjust. However, at the same time, we also considered the possibility that individuals with a strong commitment to vehicle usage would maintain a high level of gasoline consumption and would therefore remain less sensitive to changes in gasoline prices. Thus, we explicitly address this particular aspect and empirically examine how baseline gasoline consumption interacts with the price of gasoline in this subsection.

TABLE 6.

\begin{tabular}{|l|c|}
\hline & Weekly Gasoline Expenditures (won) \\
\hline 1st Quartile & 11,238 \\
\hline Median & 58,754 \\
\hline 3rd Quartile & 138,524 \\
\hline
\end{tabular}

In the presence of large differences in total and gasoline expenditures in the estimation sample, we constructed two categorical variables identifying the baseline levels of gasoline and total expenditures. "Baseline" expenditures are defined as the average weekly expenditures in the four-week-long initialization period, and the 25th, 50th, and 75th percentiles of gasoline and total expenditures were used as cutoff points for two categorical variables.

$$
\begin{aligned}
& \operatorname{Group}_{i}^{\text {total }} / \operatorname{Group}_{i}^{\text {gas }}=1 \text { if below the } 25 \text { th percentile } \\
& \operatorname{Group}_{i}^{\text {total }} / \operatorname{Group}_{i}^{\text {gas }}=2 \text { if between } 25 \text { th and } 50 \text { th percentiles } \\
& \operatorname{Group}_{i}^{\text {total }} / \operatorname{Group}_{i}^{\text {gas }}=3 \text { if between } 50 \text { th and } 75 \text { th percentiles } \\
& \operatorname{Group}_{i}^{\text {total }} / \operatorname{Group}_{i}^{\text {gas }}=4 \text { if above the } 75 \text { th percentile }
\end{aligned}
$$

To address the possible heterogeneity in the effect of gasoline prices, we included the interaction effects between the retail price of gasoline and each of two categorical variables. Using the same explanatory variables employed in the initial analyses, we developed the following model specification: 


$$
\begin{aligned}
& \log \text { GasExp }_{i t}=\sigma_{1}^{1}+\tau_{1}^{1} \log \text { GaSExpe }_{0 i}+\tau_{1}^{2} \text { Demog }_{i}+\sum_{m=1}^{4} v_{m 1}^{1} \mathrm{I}\left(\text { Group }_{i}^{\text {total }}=m\right) \\
& +\sum_{n=1}^{4} v_{n 1}^{2} \mathrm{I}\left(\text { Group }_{i}^{\text {gas }}=n\right)+\sum_{m=1}^{4} v_{m 1}^{3} \log \text { Price }_{t} \cdot \mathrm{I}\left(\text { Group }_{i}^{\text {total }}=m\right)+ \\
& \sum_{n=1}^{4} v_{n 1}^{4} \log \text { Price }_{t} \cdot \mathrm{I}\left(\text { Group }_{i}^{\text {gas }}=n\right)+\sum_{m=1}^{4} v_{m 1}^{5} \log \text { Price }_{t-1} \cdot \mathrm{I}\left(\text { Group }_{i}^{\text {total }}=m\right)+ \\
& \sum_{n=1}^{4} v_{n 1}^{6} \log \text { Price }_{t-1} \cdot \mathrm{I}\left(\text { Group }_{i}^{\text {gas }}=n\right)+\varphi_{1}^{1} X_{t}+\omega_{1 i t}^{1},
\end{aligned}
$$

$$
\begin{aligned}
& \log \text { TotalExp }_{\text {it }}=\sigma_{2}^{1}+\tau_{2}^{1} \log \text { GasExpe }_{0 i}+\tau_{2}^{2} \text { Demog }_{i}+\sum_{m=1}^{4} v_{m 1}^{1} \mathrm{I}\left(\text { Group }_{i}^{\text {total }}=m\right)+ \\
& \sum_{n=1}^{4} v_{n 1}^{2} \mathrm{I}\left(\text { Group }_{i}^{\text {gas }}=n\right)+\sum_{m=1}^{4} v_{m 2}^{3} \log \text { Price }_{t} \cdot \mathrm{I}\left(\text { Group }_{i}^{\text {total }}=m\right)+ \\
& \sum_{n=1}^{4} v_{n 2}^{4} \log \text { Price }_{t} \cdot \mathrm{I}\left(\text { Group }_{i}^{\text {gas }}=n\right)+\sum_{m=1}^{4} v_{m 2}^{5} \log \text { Price }_{t-1} \cdot \mathrm{I}\left(\text { Group }_{i}^{\text {total }}=m\right)+ \\
& \sum_{n=1}^{4} v_{n 2}^{6} \log \text { Price }_{t-1} \cdot \mathrm{I}\left(\text { Group }_{i}^{\text {gas }}=n\right)+\varphi_{2}^{1} X_{t}+\omega_{2 i t}^{1},
\end{aligned}
$$

where $\mathrm{I}\left(\operatorname{Group}_{i}^{\text {total }}=k\right)=1$ if $\operatorname{Group}_{i}^{\text {total }}=k$ and $\mathrm{I}\left(\operatorname{Group}_{i}^{\text {total }}=k\right)=0$ otherwise. This specification allowed us to distinguish among individuals according to their individual total and gasoline expenditures during the initialization period. For an individual with Group total $=m$ and Group $_{i}^{\text {gas }}=n, v_{m 1}^{3}+v_{n 1}^{4}$ measures the change in gasoline expenditures for a $1 \%$ price increase and $v_{m 1}^{5}+v_{n 1}^{6}$ measures the change in gasoline expenditures for a $1 \%$ price increase in the past week.

Table 7 reports the coefficient estimates and their standard errors. The first overarching point to be noted in the estimation results is that an increase in gasoline prices was associated with statistically-significant changes in gasoline expenditures for all groups, whereas considerable heterogeneity in individual responses to the change in gasoline prices was witnessed. More specifically, individuals with larger baseline gasoline consumption and higher income level turned out to maintain more inelastic demand for gasoline. The current findings confirm the role of income in how gasoline prices affect fuel consumption and, at the same time, empirically supports the argument that the population with a strong commitment to vehicle usage maintains a high level of fuel consumption and remains less sensitive to changes in gasoline prices.

TABLE 7.

Estimation Results for Model with Segmentation Variables

\begin{tabular}{|l|c|c|}
\hline & Gasoline & Public Transportation \\
\hline Expenditures during initialization period & $\begin{array}{c}0.4844^{* *} \\
(0.0058)\end{array}$ & $\begin{array}{l}0.1961^{*} \\
(0.0214)\end{array}$ \\
\hline Gasoline prices* Segment1 & $\begin{array}{c}0.2429^{* *} \\
(0.1014)\end{array}$ & $\begin{array}{l}0.0824^{* *} \\
(0.0147)\end{array}$ \\
\hline Gasoline Prices * Segment2 & $\begin{array}{l}0.3428^{* *} \\
(0.1011)\end{array}$ & $\begin{array}{l}0.0842^{* *} \\
(0.0186)\end{array}$ \\
\hline Gasoline Prices* Segment3 & $\begin{array}{l}0.4069^{* *} \\
(0.1041)\end{array}$ & $\begin{array}{l}0.0862^{* *} \\
(0.0156)\end{array}$ \\
\hline Gasoline Prices* Segment4 & $\begin{array}{l}0.4829^{* *} \\
(0.1078)\end{array}$ & $\begin{array}{l}0.0837^{* *} \\
(0.0181)\end{array}$ \\
\hline Gasoline Prices* Income1 & $0.0624^{* *}$ & $0.0481^{* *}$ \\
& $(0.0286)$ & $(0.0117)$ \\
\hline
\end{tabular}


TABLE 7. (CONT'D.)

Estimation Results for Model with Segmentation Variables

\begin{tabular}{|c|c|c|}
\hline & Gasoline & Public Transportation \\
\hline Gasoline Prices* Income2 & $\begin{array}{c}0.0856^{* *} \\
(0.0284)\end{array}$ & $\begin{array}{l}0.0307^{* *} \\
(0.0106)\end{array}$ \\
\hline Gasoline Prices* Income3 & $\begin{array}{l}0.1239 * * \\
(0.0297)\end{array}$ & $\begin{array}{l}0.0287^{* *} \\
(0.0104)\end{array}$ \\
\hline Gasoline Prices* Income4 & $\begin{array}{l}0.1526^{* *} \\
(0.0298)\end{array}$ & $\begin{array}{c}0.0267^{* *} \\
(0.0110)\end{array}$ \\
\hline Lagged Gasoline Prices* Segment 1 & $\begin{array}{l}0.0104^{* *} \\
(0.0017)\end{array}$ & $\begin{array}{l}0.0014^{* *} \\
(0.0001)\end{array}$ \\
\hline Lagged Gasoline Prices* Segment2 & $\begin{array}{l}0.0121^{* *} \\
(0.0018) \\
\end{array}$ & $\begin{array}{l}0.0018^{* *} \\
(0.0001) \\
\end{array}$ \\
\hline Lagged Gasoline Prices* Segment3 & $\begin{array}{l}0.0111^{* *} \\
(0.0017) \\
\end{array}$ & $\begin{array}{c}0.0019^{* *} \\
(0.002)\end{array}$ \\
\hline Lagged Gasoline Prices* Segment 4 & $\begin{array}{l}0.0118^{* *} \\
(0.0017)\end{array}$ & $\begin{array}{c}0.0014^{* *} \\
(0.002)\end{array}$ \\
\hline Lagged Gasoline Prices* Income1 & $\begin{array}{l}0.0128^{* *} \\
(0.0042) \\
\end{array}$ & $\begin{array}{l}0.0012^{* *} \\
(0.0004) \\
\end{array}$ \\
\hline Lagged Gasoline Prices* Income2 & $\begin{array}{l}0.0132^{* *} \\
(0.0041) \\
\end{array}$ & $\begin{array}{l}0.0009^{* *} \\
(0.0004)\end{array}$ \\
\hline Lagged Gasoline Prices* Income3 & $\begin{array}{l}0.0134^{* *} \\
(0.0042)\end{array}$ & $\begin{array}{l}0.0013^{* *} \\
(0.0004)\end{array}$ \\
\hline Lagged Gasoline Prices* Income4 & $\begin{array}{l}0.0137^{* *} \\
(0.0046) \\
\end{array}$ & $\begin{array}{c}0.0008^{* *} \\
(0.0003) \\
\end{array}$ \\
\hline Segment2 & $\begin{array}{l}0.1042^{* *} \\
(0.0324) \\
\end{array}$ & $\begin{array}{c}-0.0542^{* *} \\
(0.0217) \\
\end{array}$ \\
\hline Segment3 & $\begin{array}{l}0.1524^{* *} \\
(0.0317) \\
\end{array}$ & $\begin{array}{c}-0.0841^{* *} \\
(0.0208)\end{array}$ \\
\hline Segment4 & $\begin{array}{l}0.1874^{* *} \\
(0.0318) \\
\end{array}$ & $\begin{array}{c}-0.1012^{* *} \\
(0.0209) \\
\end{array}$ \\
\hline Income2 & $\begin{array}{c}0.2079 * * \\
(0.0241) \\
\end{array}$ & $\begin{array}{c}-0.0447^{* *} \\
(0.0081) \\
\end{array}$ \\
\hline Income3 & $\begin{array}{c}0.2748^{* *} \\
(0.0249) \\
\end{array}$ & $\begin{array}{c}-0.0487^{* *} \\
(0.0087) \\
\end{array}$ \\
\hline Income4 & $\begin{array}{l}0.2821^{* *} \\
(0.0236) \\
\end{array}$ & $\begin{array}{c}-0.0514^{* *} \\
(0.0084) \\
\end{array}$ \\
\hline Gender dummy & $\begin{array}{c}0.0174 \\
(0.0219) \\
\end{array}$ & $\begin{array}{c}0.0110 \\
(0.0121) \\
\end{array}$ \\
\hline 2nd quarter & $\begin{array}{c}0.1047 \\
(0.0698) \\
\end{array}$ & $\begin{array}{c}0.0044 \\
(0.0224) \\
\end{array}$ \\
\hline 3rd quarter & $\begin{array}{c}0.1001 \\
(0.0687) \\
\end{array}$ & $\begin{array}{c}0.0084 \\
(0.0217) \\
\end{array}$ \\
\hline 4th quarter & $\begin{array}{l}0.1406^{* *} \\
(0.0694)\end{array}$ & $\begin{array}{c}0.0074 \\
(0.0268) \\
\end{array}$ \\
\hline $30 \mathrm{~s}$ & $\begin{array}{c}0.0472^{* *} \\
(0.0100) \\
\end{array}$ & $\begin{array}{l}0.0625^{* *} \\
(0.0218) \\
\end{array}$ \\
\hline $40 \mathrm{~s}$ & $\begin{array}{l}0.0849 * * \\
(0.0098)\end{array}$ & $\begin{array}{l}0.0625^{* *} \\
(0.0214) \\
\end{array}$ \\
\hline
\end{tabular}




\begin{tabular}{|l|c|c|}
\hline & Gasoline & Public Transportation \\
\hline $50 \mathrm{~s}$ & $\begin{array}{c}0.0684^{* *} \\
(0.0099)\end{array}$ & $\begin{array}{c}0.0647^{* *} \\
(0.0217)\end{array}$ \\
\hline \multirow{2}{*}{$60 \mathrm{~s}$} & $\begin{array}{c}0.0842^{* *} \\
(0.0101)\end{array}$ & $\begin{array}{c}-0.0841^{* *} \\
(0.0219)\end{array}$ \\
\hline \multirow{2}{*}{ Intercept } & $\begin{array}{c}-1.6847^{* *} \\
(0.283)\end{array}$ & $\begin{array}{c}0.5471^{* *} \\
(0.217)\end{array}$ \\
\hline $\mathrm{N}$ & 72,479 & 72,954 \\
\hline Adjusted R-squared & 0.154 & 0.068 \\
\hline
\end{tabular}

${ }^{*} p<0.05 ;{ }^{* *} p<0.01$

Note: Standard errors are shown in parentheses.

Turning to the model of transit expenditures, there was limited heterogeneity in individual responses across segments. Yet, for the decrease in gasoline prices, individuals with low income generally decreased their transit ridership to a greater extent, and, more interestingly, the effect of gasoline prices decrease monotonically with baseline gasoline expenditures. We interpret the results as low-income populations made sufficient adjustments in their gasoline consumption to retain persistent gasoline expenditures irrespective of the retail prices of gasoline and switched to public transit to reduce their vehicle use.

To sum up, after explicitly controlling for heterogeneity across individuals, we found empirical evidence that financial constraints and commitment to vehicle usage have significant interaction effects with the price of gasoline. Our results confirm that the population switches between private vehicle use and ridership on public transit and identify how the effect of gasoline prices differs across segments of the population. Adding substantive empirical knowledge about public transit ridership and the demand for gasoline, our findings provide important guidance for policymakers and practitioners, and we address the implications of our findings in the next section.

\section{Discussion}

In an empirical investigation using unique panel data on individual expenditures, we found that gasoline prices had a statistically-significant effect on gasoline and transit expenditures, with the presence of considerable heterogeneity. Confirming the moderating effect of financial constraints, the analyses yielded empirical evidence showing that commitment to vehicle usage also plays an important role in determining sensitivities to the price of gasoline and ridership on public transit.

Our findings have an important implication for policymakers. With growing concerns about carbon emissions and energy security, higher gasoline prices have been imposed to induce a shift from private vehicle traffic to public transit in many industrialized countries. However, as described in the previous section, relatively inelastic demand for gasoline implies only a limited regulative effect despite the strong fiscal effect. 
In particular, a noteworthy feature is that individuals with inelastic gasoline demand generally consume the largest amount of fuel. Given that vehicle use is considered more essential for work and business trips (e.g, Storchmann 2001), such findings indicate that the relative inelastic demand of these segments can be closely linked to the productivities of other sectors in the economy. This particular aspect also was confirmed by our data, in that the individuals with high levels of gasoline consumption purchased significantly more often during weekdays (see Table 8) - which is important because drivers usually follow weekday routines and trips for leisure or recreation during weekends can be greatly reduced, particularly in comparison to work commutes. Raised fuel taxes, therefore, can have an adverse effect on productivities and induce deficits in different sectors. This aspect should not be overlooked, especially because a substantial increase in gasoline prices often accompanies a significant negative shock to the economy.

\section{TABLE 8.}

\begin{tabular}{|l|c|c|}
\hline & During Weekdays & Total \\
\hline Gas Expenditures 1 & $0.1625(62.69 \%)$ & 0.2592 \\
\hline Gas Expenditures 2 & $0.5415(60.52 \%)$ & 0.8947 \\
\hline Gas Expenditures 3 & $1.3006(82.38 \%)$ & 1.5789 \\
\hline Gas Expenditures 4 & $2.3574(94.59 \%)$ & 2.4923 \\
\hline
\end{tabular}

Given these considerations, to reduce environmental problems, alternative means of transportation must be provided for individuals with a strong commitment to vehicle use. In addition to subsidies for public transit services or reduced fares for worker or student tickets, for example, investment in and policies advocating for more fuelefficient or alternative-fuel vehicles are necessary. Government incentives to promote or develop fuel cell or electric vehicles using profits from higher fuel taxes help reduce the levels of carbon in the atmosphere without further disrupting productivities. The restricted scope of our paper does not allow us to counterfactual such policy intervention; rather, the primary objective of this discussion is to present a particular implication for practitioners and policymakers. Thus, we hope our research stimulates further efforts to investigate our argument.

\section{Conclusion}

Based on panel data on gasoline and transit expenditures, we examined how gasoline prices impact gasoline consumption and ridership on public transit. The unique feature of our data allowed us to address possible heterogeneity in the effect of gasoline prices, and our analyses yielded strong empirical evidence that financial constraints and commitment to vehicle use determine individual sensitivities to the price of gasoline and modal shift between private vehicle use and public transit ridership. In particular, the low-income population reduced gasoline consumption and increased their transit ridership during the period of rising gasoline prices; the high-income population with a 
strong commitment to vehicle use maintained fairly inelastic demand for gasoline and public transit.

Our findings contribute substantive empirical knowledge about individual decisions between public transit and private vehicle use. Extensive studies have been compiled to address the effect of gasoline prices on gasoline consumption and transit ridership. However, such studies are typically conducted at an aggregate level based on data for either fuel consumption or transit ridership. As a result, less is known about individual responses to changes in gasoline prices and how decisions concerning fuel consumption and transit ridership relate to each other, and our study concerned itself primarily with this issue.

We note that our findings concern the short-run effect of gasoline prices and provide limited implications about how gasoline prices influence gasoline consumption and ridership on public transit over longer time horizons. Nevertheless, we have witnessed that short-run changes in gasoline prices have a significant effect on the economy, and, therefore, it is important to understand the effect in the short run.

\section{Acknowledgments}

This work was supported by the 2016 Hongik University Research Fund.

\section{References}

Agathe, D. E., and R. B. Billings. 1978. "The Impact of Gasoline Prices on Urban Bus Ridership." Annals of Regional Science, 12(1): 90-96.

Allenby, G. M., Shively, T. S., Yang, S., and Garratt, M. J. 2004. "A Choice Model for Packaged Goods: Dealing with Discrete Quantities and Quantity Discounts." Marketing Science, 23(1): 95-108.

Anderson, E. T., and D. I. Simester. 1998. "The Role of Sale Signs." Marketing Science, 17(2): 139-155.

Assmus, G. 1984. "New product forecasting." Journal of Forecasting 3(2): 121-138.

Bhat, C.R., S. Sen, and N. Eluru. 2009. "The Impact of Demographics, Built Environment Attributes, Vehicle Characteristics, and Gasoline Prices on Household Vehicle Holdings and Use," Transportation Research Part B, 43(1): 1-18

Briesch, R. A., P. K. Chintagunta, and E. J. Fox. 2009. "How Does Assortment Affect Grocery Store Choice?" Journal of Marketing Research 46(2): 176-189.

Bucklin, R. E., S. Gupta, and S. Han. 1995. "A Brand's Eye View of Response Segmentation in Consumer Brand Choice Behavior." Journal of Marketing Research: 66-74.

Busse, M. R., C. R. Knittel, and F. Zettelmeyer. 2012. "Stranded Vehicles: How Gasoline Taxes Change the Value of Households' Vehicle Assets." Working paper.

Currie, G., and J. Phung. 2007. "Transit Ridership, Auto Gas Prices, and World Events: New Drivers of Change?" Transportation Research Record, 1992: 3-10. 
Cutler, D. M. 1991. "Macroeconomic Performance and the Disadvantaged." Brookings Papers on Economic Activity, 1991(2): 1-74.

Dahl, C., and T. Sterner. 1991. "Analysing Gasoline Demand Elasticities: A Survey. Energy Economics, 13(3): 203-210.

Dahl, C. 1995. "Demand for Transportation Fuels: A Survey of Demand Elasticities and Their Components. Journal of Energy Literature, 1(2): 3-27.

Dahl, C. 1986. “Gasoline Demand Survey," Energy Journal, 7(1): 67-82

Drollas, L. P. 1984. “The Demand for Gasoline: Further Evidence." Energy Economics, 6(1): 71-82.

Dubé, J-P., and S. Gupta. 2008. "Cross-brand Pass-through in Supermarket Pricing." Marketing Science, 27(3): 324-333.

Economy Watch. 2010. US Fossil Fuel Dependency. http://www.economywatch.com/ fossil-fuels-dependency/dependency-in-america.html, accessedFebruary18, 2016.

Espey, M. 1996. "Explaining the Variation in Elasticity Estimates of Gasoline Demand in the United States: A Meta-Analysis." The Energy Journal: 49-60.

Espey, M. 1997. "Pollution Control and Energy Conservation: Complements or Antagonists? A Study of Gasoline Taxes and Automobile Fuel Economy Standards." The Energy Journal: 23-38.

Espey, M. 1998. "Gasoline Demand Revisited: An International Meta-Analysis of Elasticities." Energy Economics 20(3): 273-295.

Gicheva, D., J. Hastings, and S. Villas-Boas. 2010. "Investigating Income Effects in Scanner Data: Do Gasoline Prices Affect Grocery Purchases?." The American Economic Review 100(2): 480-484.

Goldberg, P. K. 1998. "The Effects of the Corporate Average Fuel Efficiency Standards in the US." The Journal of Industrial Economics 46(1): 1-33.

Golub, A. 2010. "Welfare and Equity Impacts of Gasoline Price Changes under Different Public Transportation Service Levels." Journal of Public Transportation,13(3): 1.

Gramlich, J. P. 2009. "Gas Prices and Fuel Efficiency in the US Automobile Industry: Policy Implications of Endogenous Product Choice."

Haire, A., and R, Machemehl. 2007. "Impact of Rising Fuel Prices on US Transit Ridership." Transportation Research Record, 1992: 11-19.

Hoch, S. J., B. D. Kim, A. L. Montgomery, and P. E. Rossi. 1995. "Determinants of StoreLevel Price Elasticity." Journal of Marketing Research: 17-29.

Horowitz, J. 1982. "Modeling Traveler Responses to Alternative Gasoline Allocation Plans." Transportation Research Part A: General, 16(2): 117-133.

Institute for Energy Research. 2015. “IMF's Disingenuous Attempt to Tax Energy Use." http://instituteforenergyresearch.org/analysis/imfs-disingenuous-attempt-to-taxenergy-use/, accessedFebruary18, 2016. 
Johnson, D., and T. Smeeding. 1998. "Measuring the Trends in Inequality of Individuals and Families: Income and Consumption." Washington, DC, March.

Kim, B-D., and P. E. Rossi. 1994. "Purchase Frequency, Sample Selection, and Price Sensitivity: The Heavy-User Bias." Marketing Letters, 5(1): 57-67.

Kitamura, R. 1989. "A Causal Analysis of Car Ownership and Transit Use." Transportation, 16(2): $155-73$.

Litman, T., 2007. "Evaluating Rail Transit Benefits: A Comment." Transport Policy, 14(1): 94-97.

Ma, Y., et al. 2011. "An Empirical Investigation of the Impact of Gasoline Prices on Grocery Shopping Behavior." Journal of Marketing, 75(2): 18-35.

Masayuki, D., and Allen, W. B. 1986. A Time-Series Analysis of Monthly Ridership for an Urban Rail Rapid Transit Line." Transportation, 13(3): 257-269.

Mattson, J. W. 2008. "Effects of Rising Gas Prices on Bus Ridership for Small Urban and Rural Transit Systems." Upper Great Plains Transportation Institute, North Dakota State University.

McFadden, D., Talvitie, A., Cosslett, S., Hasan, I., Johnson, M., Reid, F., and Train, K. 1977. "Demand Model Estimation and Validation." Urban Travel Demand Forecasting Project, Phase 1.

McLeod, M. S., Jr., K. Flannelly, L. Flannelly, and R. Behnke. 1991. “Multivariate TimeSeries Model of Transit Ridership Based on Historical, Aggregate Data: The Past, Present, and Future of Honolulu." Transportation Research Record, 1297: 76-84.

Navin, F. P. D. 1974. "Urban Transit Ridership in an Energy Supply Shortage." Transportation Research, 8(4): 317-327.

Nizlek, M. C., and L. Duckstein. 1974. "A System Model for Predicting the Effect of Energy Resources on Urban Modal Split." Transportation Research, 8.4(5): 329-334.

Rose, G. 1986. "Transit Passenger Response: Short and Long Term Elasticities Using Time Series Analysis." Transportation, 13(2): 131-141.

Sagner, J. S. 1974. "The Impact of the Energy Crisis on American Cities based on Dispersion of Employment, Utilization of Transit, and Car Pooling." Transportation Research, 8(4-5): 307-316.

Sanchez, T. W. 1999. "The Connection between Public Transit and Employment: The Cases of Portland and Atlanta." Journal of the American Planning Association, 65(3): 284-296.

Sanchez, T. W., Q. Shen, and Z-R. Peng. 2004. "Transit Mobility, Jobs Access and LowIncome Labour Participation in US Metropolitan Areas." Urban Studies, 41(7): 13131331.

Schipper, L., Figueroa, M. J., Price, L., and Espey, M. 1993. “Mind the Gap: The Vicious Circle of Measuring Automobile Fuel Use." Energy Policy, 21(12): 1173-1190. 
Sterner, T. 1990. "The Pricing of and Demand for Gasoline." TFB-Rapport.

Storchmann, K-H. 2001. "The Impact of Fuel Taxes on Public Transport-An Empirical Assessment for Germany." Transport Policy, 8(1: 19-28.

Taylor, B. D., and C. Fink. 2003. "The Factors Influencing Transit Ridership: A Review and Analysis of the Ridership Literature." University of California Transportation Center.

Tellis, G. J. 1998. "The Price Elasticity of Selective Demand: A Meta-analysis of Econometric Models of Sales." Journal of Marketing Research: 331-341.

U.S. Energy Information Administration. 2015. Korea, South: International Energy Data and Analysis. https://www.eia.gov/beta/international/analysis_includes/countries_ long/Korea_South/south_korea.pdf, accessedFebruary18, 2016.

Wakefield, K. L., and J. J. Inman. 2003. "Situational Price Sensitivity: The Role of Consumption Occasion, Social Context and Income." Journal of Retailing, 79(4): 199-212.

Wang, T., and Chen, C. 2014. "Impact of Fuel Price on Vehicle Miles Traveled (VMT): Do the Poor Respond in the Same Way as the Rich? Transportation, 41: 91-105.

Wang, G., and D. Skinner. 1984. "The Impact of Fare and Gasoline Price Changes on Monthly Transit Ridership: Empirical Evidence from Seven US Transit Authorities." Transportation Research Part B: Methodological, 18(1): 29-41.

Wolff, G. J., and D. M. Clark. 1982. "Impact of Gasoline Price on Transit Ridership in Fort Worth, Texas." Journal of Transportation Engineering, 108.TE4.

\section{About the Authors}

HoJIN JUNG (hojin@hongik.ac.kr) earned a Ph.D. in Marketing from the Kellogg School of Management at Northwestern University in 2012. He is an Assistant Professor at the College of Business Administration at Hongik University. His research interests focus on the development and applications of quantitative models for understanding consumer behaviors.

Dr. GUN JeA YU (gy52@hongik.ac.kr) has a Ph.D. in Industrial Labor and Relations from Cornell University and is an Assistant Professor at the College of Business Administration at Hongik University. His current research is focused on strategic management and innovation.

KYounG-MIN KwoN (km.kwon@hongik.ac.kr) earned a Ph.D. in Finance from Michigan State University in 2012. He is an Assistant Professor of Finance at Hongik University College of Business Administration. His research interest includes corporate finance, corporate governance and product markets. 